\title{
Peran kepemimpinan dalam meningkatkan kualitas sumber daya manusia (Studi pada pemerintah desa tonasa dan desa mamampang, tombolo pao)
}

\author{
Suhartono \\ Universitas Islam Negeri Alauddin Makassar \\ Nurarini Arsyad \\ Universitas Islam Negeri Alauddin Makassar \\ Finna Amelia \\ Universitas Islam Negeri Alauddin Makassar \\ Email \\ finnaamelia22@gmail.com
}

\begin{abstract}
Abstrak
Peran kepemimpinan sangat menunjang tercapainya sumber daya manusia yang berkualitas dalam pemerintah desa, salah satunya dengan membentuk eksistensi kepala desa yang diyakini dapat mengimbangi pola pikir dan refleksi paradigma baru dalam arus globalisasi. Penelitian ini bertujuan untuk mengetahui peran kepala desa dalam meningkatkan kualitas sumber daya manusia pada lingkup aparatur pemerintah desa. Penelitian ini merupakan penelitian kualitatif. Hasil penelitian menunjukkan bahwa peran kepemimpinan dalam meningkatkan kualitas sumber daya manusia di desa Tonasa dan desa Mamampang dapat di lihat berdasarkan peran kepala desa sebagai Interpersonal role (Peranan pribadi), Decision making (peranan pembuat keputusan), dan Informational role (peranan sumber informasi). Ketiga peran pemimpin tersebut sudah di jalankan oleh kepala desa di desa Tonasa dan desa Mamampang dimana dalam interpersonal role kepala desa menempatkan dirinya sebagai Figurehead, Leader dan Liaison. Dalam Decision making, kepala desa menempatkan dirinya sebagai Entrepreneur, Distrubance handler, Resource allocation, dan Negotiator. Dan dalam Informational role kepala desa menempatkan dirinya sebagai Monitor and dessiminator dan Spoke person. Sehingga terciptalah sumber daya manusia yang berkualitas.
\end{abstract}

Kata Kunci: Peran, kepemimpinan, kualitas sumber daya manusia, kepala desa.

\section{Pendahuluan}

Sumber daya manusia merupakan faktor yang sangat penting dalam sebuah organisasi baik organisasi dalam skala besar maupun kecil. Pada organisasi berskala besar, sumber daya manusia dipandang sebagai unsur yang sangat menentukan dalam proses pengembangan usaha, peran sumber daya manusia menjadi semakin penting. Perkembangan pemerintahan akan terealisasi apabila ditunjang oleh aparatur negara yang berkualitas (Syafitri dan Lilis 2019). Kemampuan pegawai sebagai sumber daya manusia dalam suatu organisasi sangat penting arti dan keberadaannya untuk peningkatan produktivitas kerja di lingkungan organisasi. Manusia merupakan salah satu unsur terpenting yang menentukan berhasil atau tidaknya suatu organisasi dalam mencapai tujuan dan mengembangkan misinya. Sumber daya manusia yang berkualitas juga dapat menghemat waktu pembuatan laporan keuangan, disebabkan karena sumber daya manusia tersebut telah mengetahui dan memahami apa yang 
akan dikerjakan dengan baik dan sesuai bidangnya sehingga penyajian laporan keuangan bisa tepat waktu. Semakin cepat waktu penyajian laporan keuangan, maka semakin baik untuk pengambilan keputusan (Mardiasmo 2020).

Dalam organisasi publik, pegawai bekerja selalu tergantung pada pimpinan. Bila pimpinan tidak memiliki kemampuan memimpin, maka tugas-tugas yang sangat kompleks tidak dapat dikerjakan dengan baik. Apabila manajer mampu melaksanakan fungsi-fungsinya dengan baik, sangat mungkin organisasi tersebut dapat mencapai sasarannya. Suatu organisasi membutuhkan pemimpin yang efektif, yang mempunyai kemampuan mempengaruhi perilaku anggotanya atau anak buahnya. Jadi, seorang pemimpin atau kepala suatu organisasi akan diakui sebagai seorang pemimpin apabila ia dapat memberi pengaruh dan mampu mengarahkan bawahannya ke arah tujuan organisasi (Suardi 2017).

Kepemimpinan merupakan salah satu isu dalam manajemen yang masih cukup menarik untuk diperbincangkan hingga dewasa ini. Media massa, baik elektronik maupun cetak, seringkali menampilkan opini dan pembicaraan yang membahas seputar kepemimpinan. Peran kepemimpinan yang sangat strategis dan penting bagi pencapaian misi, visi dan tujuan suatu organisasi, merupakan salah satu motif yang mendorong manusia untuk selalu menyelidiki seluk-beluk yang terkait dengan kepemimpinan (Yahdiani dkk 2020).

Seorang pemimpin atau kepala suatu organisasi akan diakui sebagai seorang pemimpin apabila ia dapat memberi pengaruh dan mampu mengarahkan bawahannya ke arah tujuan organisasi. Dalam rangka meningkatkan citra, kerja dan kinerja instansi pemerintah menuju kearah profesionalisme dan menunjang terciptanya pemerintahan yang baik (good governance), perlu adanya penyatuan arah dan pandangan bagi segenap jajaran pegawai pemerintah yang dapat dipergunakan sebagai pedoman atau acuan dalam melaksanakan tugas baik manajerial maupun operasional diseluruh bidang tugas dan unit organisasi instansi pemerintah secara terpadu (Sineke et.al. 2017).

Dalam meningkatkan kualitas sumber daya manusia tentu peran kepemimpinan sangatlah penting. Oleh karena itu, pemimpin dituntut untuk mampu secara terampil membimbing organisasi menuju arah strategi yang baru. Salah satu bentuk kepemimpinan yang diyakini dapat mengimbangi pola pikir dan refleksi paradigma baru dalam arus globalisasi. Kepemimpinan, digambarkan sebagai gaya kepemimpinan yang dapat membangkitkan atau memotivasi pegawai, sehingga dapat berkembang dan mencapai kinerja pada tingkat yang tinggi melebihi dari apa yang mereka perkirakan sebelumnya (Kushandajani dan Indah 2020).

Peran pemimpin dalam menjelaskan apa yang harus dikerjakan atau mengarahkan bawahannya sangat berpengaruh dengan melakukan berbagai hal yang kiranya dapat memberikan dampak terhadap pengembangan sumber daya yang ada. Maka kepemimpinan sebagai salah satu hal penting yang harus diperhatikan dalam proses pengembangan sumber daya aparatur dalam internal organisasi pemerintah ini menyangkut tentang aspek komitmen pimpinan lembaga ataupun instansi tertentu dalam meningkatkan kualitas sumber daya manusia. Misalnya dalam lingkup pemerintahan Desa, kepala desa yang merupakan pimpinan tertinggi di desa. Sehingga, Kepala desa mempunyai andil penting dalam kemajuan suatu desa. Sebagai seorang pemimpin, kepala desa dituntut untuk bisa melaksanakan tugas dan tanggung jawabnya dengan baik. Salah satu peranan yang sangat penting dalam proses pengelolaan suatu organisasi adalah kemampuan mengintegrasikan berbagai kegiatan yang diselenggarakan oleh satuan-satuan kerja yang ada dibawahnya demi terwujudnya kesatuan gerak dan memudahkan dalam pencapaian tujuan organisasi. Integrasi demikian tidak akan terwujud jika seorang pimpinan tidak mampu menjalankan fungsi dan perannya dengan baik (Dominggus dan Adhitama 2019). 
Berdasarkan latar belakang di atas, dapat dijelaskan bahwa keberhasilan suatu organisasi sangat dipengaruhi oleh pimpinanannya. Peran pemimpin yang tepat pada situasi dan kondisi organisasi tertentu dapat meningkatkan kualitas sumber daya manusia. Oleh karena itu, yang menjadi rumusan masalah dalam penelitian ini adalah bagaimana peran kepala desa dalam meningkatkan kualitas sumber daya manusia pada lingkup aparatur pemerintah desa.

\section{Tinjauan Pustaka}

\section{Teori Kepemimpinan}

Teori kepemimpinan Menurut George R. Terry (dalam Suardi Reza Hafikar 2017 ) mengemukakan sejumlah teori kepemimpinan di antaranya :

\section{Teori Otokratis}

Kepemimpinan menurut teori ini didasarkan atas perintah-perintah, paksaan, dan tindakan-tindakan yang arbiter (sebagai wasit). Ia melakukan pengawasan yang ketat agar semua pekerjaan berlangsung secara efisien. Kepemimpinannya berorientasi pada struktur organisasi dan tugas-tugas. Pemimpin tersebut pada dasarnya selalu mau berperan sebagai pemain orkes tunggal dan berambisi untuk merajai situasi. Oleh karena itu, dia disebut sebagai otokrat keras. Adapun ciri-ciri khasnya antara lain :

- Dia memberikan perintah-perintah yang dipaksakan dan harus dipatuhi.

- Dia menentukan policy/kebijakan untuk semua pihak tanpa berkonsultasi dengan para anggota.

- Dia tidak pernah memberikan informasi mendetail tentang rencana-rencana yang akan datang, akan tetapi cuma memberitahukan pada setiap anggota kelompoknya langkah-langkah segera yang harus mereka lakukan.

- Dia memberikan pujian atau kritik pribadi terhadap setiap anggota kelompoknya dengan inisiatif sendiri. Sikapnya selalu menjauhi kelompoknya (menyisihkan diri) sebab ia menganggap diri sendiri sangat istimewa atau eksklusif. Ringkasnya, ia ibarat sebuah sistem pemanas kuno, yang memberikan energinya tanpa mempertimbangkan iklim emosional lingkungannnya.

\section{Teori Psikologis}

Teori ini menyatakan bahwa fungsi seorang pemimpin adalah memunculkan dan mengembangkan sistem motivasi terbaik, untuk merangsang kesediaan bekerja dari para pengikut dan anak buah. Pemimpin merangsang bawahan agar mereka mau bekerja guna mencapai sasaran-sasaran organisatoris maupun untuk memenuhi tujuan-tujuan pribadi. Maka kepemimpinan yang mampu memotivasi orang lain akan mementingkan aspek-aspek psikis manusia seperti pengakuan (recognizing), martabat, status sosial, kepastian emosional, memeperhatikan keinginan dan kebutuhan pegawai, kegairahan kerja, minat, suasana hati dan lain-lain. 
3. Teori Sosiologis

Kepemimpinan dianggap sebagai usaha-usaha untuk melancarkan antar relasi dalam organisasi, dan sebagai usaha untuk menyelesaikan setiap konflik organisatoris antara para pengikutnya, agar tercapai kerja sama yang baik. Pemimpin menetapkan tujuan-tujuan, dengan menyertakan para pengikut dalam pengambilan keputusan terakhir. Selanjutnya juga mengidentifikasi tujuan, dan kerap kali memberikan petunjuk yang diperlukan bagi para pengikut untuk melakukan setiap tindakan yang berkaitan dengan kepentingan kelompok. Setiap anggota mengetahui hasil apa, keyakinan apa, dan kelakuan apa yang diharapkan dari mereka oleh pemimpin dan kelompoknya. Pemimpin diharapkan dapat mengambil tindakan-tindakan korektif apabila terdapat kepincangan-kepincangan dan penyimpangan-penyimpangan dalam organisasi.

\section{Teori Suportif}

Menurut teori ini, para pengikut harus berusaha sekuat mungkin dan bekerja dengan penuh gairah, sedang pemimpin akan membimbing dengan sebaikbaiknya melalui policy tertentu. Untuk maksud ini, pemimpin perlu menciptakan suatu lingkungan kerja yang menyenangkan dan bisa membantu mempertebal keinginan setiap pengikutnya untuk melaksanakan pekerjaan sebaik mungkin, sanggup bekerja sama dengan pihak lain, mau mengembangkan bakat dan keterampilannnya dan menyadari benar keinginan sendiri untuk maju.

\section{Konsep Kualitas}

Menurut Joseph M. Juran (dalam M. N. Nasution, 2005) mendefinisikan kualitas sebagai kesesuaian untuk digunakan (fitness for use), yang mengandung pengertian bahwa suatu produk atau jasa harus dapat memenuhi apa yang diharapkan oleh pemakainya. Sedangkan menurut DIN ISO 8402 (dalam Azrul Azwar, 1996:48) mendefinisikan bahwa mutu adalah kualitas dari wujud serta ciri dari suatu barang atau asa, yang didalamnya terkandung sekaligus pengertian rasa aman atau pemenuhan kebutuhan para pegguna.

Winston Dictionary 8420 (dalam Azrul Azwar, 1996:48) mendifinisikan "mutu adalah tingkat kesempurnaan dari penampilan sesuatu yang sedang diminati". Pada dasarnya kualitas mengacu kepada pengertian pokok dimana kualitas terdiri dari sejumlah keistimewaan produk, baik keistimewaan langsung maupun keistimewaan atraktif. Keistimewaan langsung berkaitan dengan kepuasan pelanggang yang diperoleh secara langsung dengan mengkomsumsi produk yang memiliki karakteristik unggul. Sedangkan keistimewaan atraktif berkaitan dengan kepuasan masyarakat yang diperoleh secara tidak langsung dengan mengkomsumsi produk itu. Kualitas juga terdiri dari segala sesuatu bebas dari kekurangan atau kerusakan (Kumalasari 2016).

\section{Karakteristik Kepemimpinan}

Kepemimpinan merupakan cermin bagaimana organisasi dijalankan, sehingga di dalam organisasi tersebut nampak adanya keterlibatan menyeluruh orang-orang yang menjalankan tugas-tugas, melaksanakan metode, pola serta sistem dan kebijaksanaan tertentu sehingga mampu menjalankan kewajibannya untuk mencapai tujuan yang diharapkan. Dalam kenyataannya setiap pemimpin sangat besar peranannya terhadap anggota organisasi, yang 
terlihat dalam gaya perilaku pada waktu melaksanakan tugas dan tanggung jawabnya (Galip 2018).

Dalam kepemimpinan ada beberapa unsur dan karakter yang sangat menentukan untuk pencapaian tujuan suatu organisasi. Menurut Gibb (Rahmi 2014), ada empat elemen utama dalam kepemimpinan yang saling berkaitan satu sama lain, yaitu Pemimpin yang menampilkan kepribadian pemimpin, Kelompok, Pengikut yang muncul dengan berbagai kebutuhannya, sikap serta masalah-masalahnya, dan situasi yang meliputi keadaan fisik dan tugas kelompok.

\section{Peranan Pemimpin}

Menurut Henry Mintzberg (Badeni 2014) kepemimpinan memiliki tiga peran utama yang biasanya dijalankan oleh pimpinan dalam meningkatkan suatu kinerja atau manajemen dalam suatu organisasi, yaitu sebagai berikut:
a. Interpersonal role (Peranan pribadi).
b. Decision making (peranan pembuat keputusan).
c. Informational role (peranan sumber informasi).

\section{Kualitas Sumber Daya Manusia}

Menurut Sumardjan dalam Mokodompis (dalam Hendra 2011) bahwa manusia seutuhnya yang berkualitas adalah manusia-manusia pembangunan yang memiliki ciri:

- Mempunyai kepercayaan atas dirinya sendiri, tidak boleh rendah diri yang menimbulkan sikap pasrah atau menyerah pada nasib, sehingga ia menjadi pasif atau apatis terhadap kemungkinan untuk memperbaiki nasibnya.

- Mempunyai keinginan yang kuat untuk memperbaiki nasibnya.

- Mempunyai watak yang dinamis antara lain:

a. Memanfaakan setiap kesempatan yang menguntungkan

b. Mampu memecahkan persoalan hidup yang dihadapi

c. Selalu siap menghadapi perubahan social budaya yang terjadi dalam masyarakat

d. Bersedia dan mampu bekerja sama dengan pihak lain atas dasar pengertian dan penghormatan hak serta kewajiban masing-masing pihak.

- Mempunyai watak yang bermoral tinggi, antara lain: jujur, menepati janji, peka hak dan kepentingan pihak lain.

\section{Kerangka pikir}

Peran kepemimpinan sangat penting dalam meningkatkan kualitas sumber daya manusia. Peran kepemimpinan dapat di ukur dari teori kepemimpinan dan konsep kualitas yang kemudian tercipta peningkatan kualitas sumber daya manusia. Adapun gambaran rerangka teoritis mengenai peran kepemimpinan dalam meningkatkan kualitas sumber daya manusia adalah sebagai berikut. 


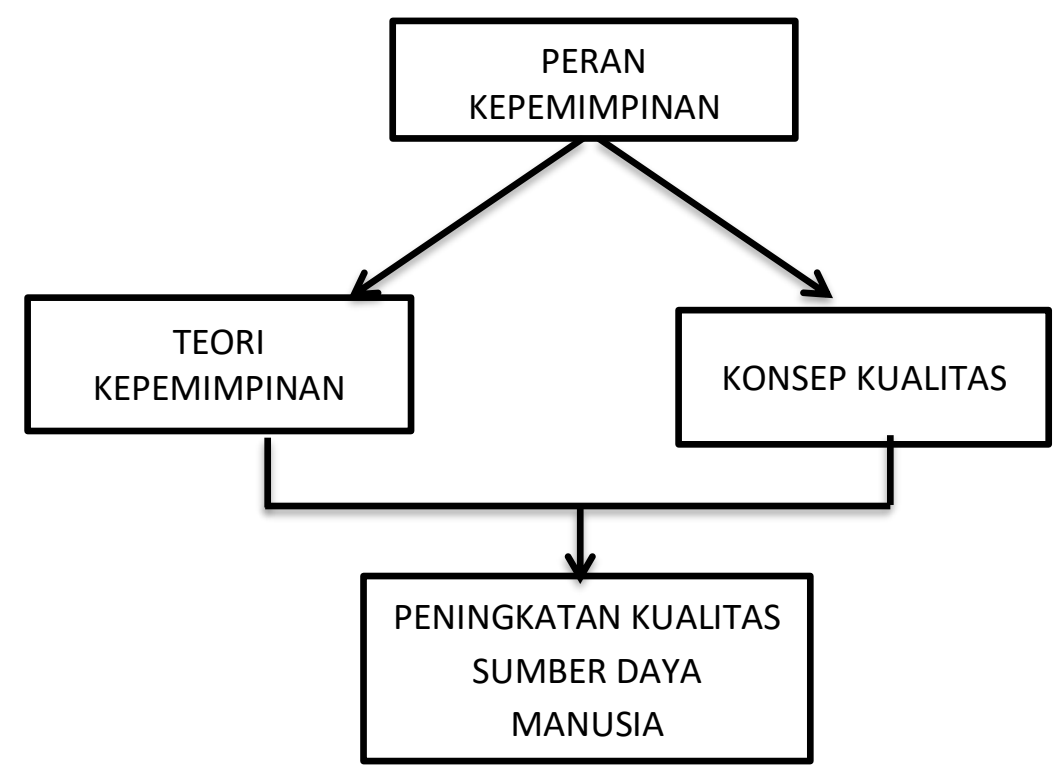

Gambar 1. Kerangka Pikir

\section{Metodologi Penelitian}

\section{Jenis Penelitian Dan Lokasi Penelitian}

Jenis penelitian yang digunakan dalam penelitian ini adalah penelitian kualitatif yaitu sebuah metode penelitian yang digunakan dalam mendeskrsipsikan peranan kepala desa dalam meningkatkan kualitas sumber daya manusia.

Lokasi penelitian ini adalah di Desa Tonasa Dan Desa Mamampang, Kecamatan Tombolo Pao, Kabupaten Gowa.

\section{Pendekatan Penelitian}

Penelitian kualitatif adalah penelitian ilmiah dengan menyandarkan kebenaran pada sisi kriteria ilmu empiris yang berusaha untuk mengeksplorasi, mendeskripsikan, menjelaskan, dan memprediksi kejadian-kejadian pada setting social (Dewi 2013). Sehingga dasar penelitian yang di gunakan adalah bersifat deskriptif yaitu menggambarkan kenyataan dari kejadian yang diteliti sehingga memudahkan peneliti untuk mendapatkan data yang objektif dalam rangka mengetahui dan memahami peran pemimpin yang diterapkan oleh kepala desa untuk meningkatkan kualitas sumber daya manusia pada tataran pemerintahan desa.

\section{Jenis Data}

Data yang dikumpulkan pada penelitian ini adalah data primer. Data primer adalah data yang diperoleh langsung oleh pengumpul data (peneliti) dari objek penelitiannya. Data ini di peroleh melalui wawancara langsung dengan para narasumber data atau informan penelitian, berkenaan dengan peranan kepala desa dalam meningkatkan kualitas sumber daya manusia. Data primer ini akan dikumpulkan dan diolah langsung oleh si peneliti.

\section{Sumber Data Penelitian (Informan)}

Salah satu sifat penelitian kualitatif adalah tidak terlalu mementingkan jumlah sumber data dan informan, tetapi lebih mementingkan isi (content), relevansi, sumber/informan yang benar-benar dapat memberikan informasi baik mengenai orang, peristiwa atau hal. Oleh 
karena itu teknik yang diambil dalam menentukan sumber/data atau informan adalah "purposive sampling" yaitu penentuan sampel sumber data berdasarkan tujuan tertentu (sugiono 2009).

Sumber data/informan dari penelitian ini diambil dari beberapa unsur atau pejabat terkait dengan efektivitas pelayanan yang dilakukan oleh kepala desa. Adapun sumber data/informan yang dimaksud adalah Kepala desa dan Aparat desa.

\section{Instrumen dan Teknik Pengumpulan Data}

Dalam penelitian kualitatif yang menjadi instrumen atau alat penelitian adalah peneliti itu sendiri. Penelitian kualitatif sebagai human instrument, berfungsi menetapkan fokus penelitian, memilih informan sebagai sumber data, melakukan pengumpulan data, menilai kualitas data, menafsirkan data dan membuat kesimpulan atas semuanya (Hijriah 2019).

\section{Analisis Data}

Analisis data dalam penelitian kualitatif, dilakukan pada saat pengumpulan data berlangsung, dan setelah pengumpulan data dalam periode tertentu. Pada saat wawancara, peneliti sudah melalukan analisis terhadap jawaban yang diwawancarai. Bila jawaban yang diwawancarai setelah dianalisis belum terasa memuaskan, maka peneliti akan melanjutkan pertanyaan lagi, sampai tahap tertentu diperoleh data yang kredibel.

\section{Hasil dan Pembahasan}

Desa Tonasa berasal dari kata "Tonasa" yang berasal dari bahasa Makassar dialeg Konjo Pegunungan atau Konjo Tombolo yang berarti "keras" merupakan inti dari kayu yang sangat keras dan kuat yang berposisi di dalam (di tengah batang kayu). Karena letak secara geografis berada di tengah-tengah wilayah kerajaan Balassuka, maka diberi nama Tonasa yang pada awal pemerintahannya di pegang oleh seorang yang bergelar Gallarrang Tonasa. Dimasa pemerintahan Kolonial Belanda, Tonasa berada dibawah kewenangan Distrik Pao sebelum dilebur menjadi satu wilayah dengan Distrik Parigi menjadi Kecamatan Tinggimoncong dengan pusat pemerintaahan di Malino.

Beberapa tahun kemudian, Desa Mangottong bersama Desa Bontopanno dilebur kedalam satu wilayah desa menjadi Desa Tamaona Kecamatan Tinggimoncong Tahun 1985 Desa Tamaona dimekarkan menjadi 3 (tiga) desa, yaitu Desa Tonasa dan Desa Erelembang sebagai desa persiapan dan Desa Tamaona sebagai desa 75 Desa Tonasa, Profil Pemerintah Desa Tonasa tahun 2016, h.3 induk dan A. Rauf Karaeng Tombong diangkat sebagai pelaksana tugas kepala desa pertama. Desa Tonasa merupakan salah satu desa dari 9 (Sembilan) Desa/Kelurahan dalam wilayah Kecamatan Tombolo Pao, Kabupaten Gowa. Secara Geografis, Desa Tonasa terletak antara 5o $11^{\text {"e } 30 " ~ L S ~-~} 5$ o 14" 30" LS dan 119o 58 0 " BT -119 o $58^{\text {ee }} 0$ " BT dengan luas wilayah $\pm 2.125,65$ ha atau $\pm 21,25 \mathrm{Km} 2$. Batas wilayah administratif Desa Tonasa Kecamatan Tombolo Pao adalah sebagai berikut:

a) Sebelah utara berbatasan dengan Kelurahan Tamaona dan Desa Mamampang.

b) Sebelah timur berbatasan dengan Desa Mamampang dan Desa Kanreapia.

c) Sebelah selatan berbatasan dengan Desa Kanreapia dan Kelurahan Pattapang.

d) Sebelah barat berbatasan dengan Kelurahan Erelembang dan Kelurahan Tamaona.

Berdasarkan data BPS dalam angka, Kecamatan Tombolo Pao, Desa Mamampang adalah salah satu desa yang ada di Kabupaten Gowa Provinsi Sulawesi Selatan, dengan luas sebesar 21,55 $\mathrm{Km}^{2}$. Sebagian besar wilayah desa mamampang adalah bertopografi daerah 
daratan tinggi dengan ketinggian rata-rata lebih dari 1000 meter di atas permukaan air laut, Pada tahun 2019 desa mamampang memiliki sarana berupa sarana kesehatan sebanyak 5 unit dan sarana pendidikan sebanyak 6 unit. Penggunaan Lahan yang ada di wilayah desa mamampang terdiri dari lahan kering dan lahan sawah. Lahan kering biasa banyak digunakan untuk perkebunan seluas 6055 hektar, sedangkan sisanya untuk tegal, ladang, dan hutan rakyat.

Letak Geografis dan Administrasi Secara geografis Desa Mamampang berada di Kabupaten Gowa Provinsi Sulawesi Selatan dengan kondisi desa sebagian besar lereng batas sebelah utara dengan Desa Pao,sebelah timur Desa Ballasuka, sebelah selatan Desa Kanreapia dan sebelah barat Desa Tonasa. Secara administrasi Kecamatan Tombolo Pao dengan luas $251,82 \mathrm{~km}^{2}$ yang meliputi 9 desa yaitu Desa Kanreapia, Desa Ballasuka, Desa Tabbingjai, Desa Mamampang, Desa Tonasa, Desa Tamaona, Desa Pao, Desa Erelembang dan Desa Bolaromang. Berdasarkan gambaran umum kedua desa tersebut penelitian ini menjawab bagaimana peran kepemimpinan dalam meningkatkan kualitas sumber daya manusia, pada tataran pemerintah desa Tonasa dan Mamampang.

Sebagaimana kepala desa merupakan pimpinan dari pemerintahan desa, masa jabatan kepala desa adalah 6 (enam) tahun, dapat di perpanjang lagi untuk satu kali masa jabatan berikutnya, kepala desa tidak bertanggung jawab kepada camat, tetapi di koordinasikan saja oleh camat. Sebagai seorang pimpinan tentu memahami bagaimana menjadi pemimpin yang baik. Sebagaimana informan memberikan keterangan bahwa:

"Kepemimpinan adalah kemampuan diri seseorang dalam mengemban amanah dan tanggung jawab demi kemaslahatan seluruh anggota masyarakat”.(Bpk. Anwar selaku kepala desa tonasa) bahwa:

Terkait wawancara tentang kepribadian pemimpin, informan memberikan keterangan

\section{"Kepribadian pemimpin yang ideal adalah mampu menjaga kata-katanya dan mampu memberikan contoh kepada masyarakat. (Bpk. Mugino selaku bendahara desa mamampang)}

Kutipan tersebut memberikan indikasi bahwa kepribadian seorang pemimpin terkait dengan peran kepemimpinan itu sendiri. Dalam pemerintahan desa di Desa Tonasa dan Desa Mamampang, peran kepemimpinannya dapat dijelaskan berdasarkan pendapat Henry Mintzberg (Badeni, 2014) dimana kepemimpinan memiliki tiga peran utama yang biasanya dijalankan oleh pimpinan dalam meningkatkan suatu kinerja atau manajemen dalam suatu organisasi yaitu terdiri dari Interpersonal role (Peranan pribadi), Decision making (peranan pembuat keputusan), dan Informational role (peranan sumber informasi).

1. Peran kepala Desa dalam interpersonal role (peranan pribadi)

Peran kepala desa dalam interpersonal role dapat dilihat dari perannya sebagai Figurehead, Leader dan Liaison. Pertama, Kepala desa sebagai figurehead, memiliki tanggung jawab terhadap legal, sosial, seremonial dan juga bertindak sebagai simbol organisasi. Seorang kepala desa menjadi sumber inspirasi. Adapun terkait peran kepala desa dalam interpersonal role, informan memberikan keterangan bahwa: 
"Kepala desa biasanya akan melakukan hal-hal seremonial seperti menghadiri acara pemotongan pita peresmian, menandatangani dokumen legal (hukum), menyapa tamu dan menjadi tuan rumah acara-acara desa". (Bpk. Mugino selaku bendahara desa mamampang)

Terkait peran kepala desa sebagai pemimpin yang harus memberikan motivasi kepada para anggotanya, Informan memberikan keterangan sebagai berikut:

"Kepala Desa yang juga sebagai pimpinan tertinggi dalam suatu desa, harusnya memotivasi dan menumbuhkan semangat belajar bagi masyarakat desa serta memberikan fasilitas yang mumpuni di setiap pelatihan dan pengembangan yang dilakukan". (Bpk. Ikhsan selaku staf desa mamampang)

Dari kutipan wawancara tersebut memaparkan bahwa peran pimpinan kepala desa Tonasa dan desa Mamampang sebagai figurehead dijalankan dengan sangat baik dimana untuk meningkatkan kinerja pegawainya dia harus memberi contoh kepada pegawainya untuk menjalankan organisasi dengan sungguh-sungguh juga dapat menjalankan perannya sebagai figurehead, yakni peranan yang dilakukan untuk mewakili organisasi yang dipimpinannya di dalam setiap kesempatan dan persoalan yang timbul secara formal.

Kedua, kepala desa sebagai Leader memiliki tugas sebagai pemimpin dalam Tim, departemen ataupun organisasinya. Menyeleksi dan memberikan ruang dalam pengembangan sumber daya manusia, serta mengelola kinerja dan memberikan motivasimotivasi untuk mencapai sasaran organisasi. Adapun mengenai peran kepala desa dalam pengembangan sumber daya manusia, informan memberikan keterangan:

"Kepala desa selalu memberikan masukan serta memberikan ruang-ruang pelatihan kecakapan bagi seluruh staf desa dengan mengirim satu persatu aparatnya mengikuti pelatihan". (Bpk. Ikhsan selaku staf desa mamampang)

Hal ini sejalan dengan teori psikologis dimana seorang kepala desa sering memberikan motivasi- motivasi, untuk merangsang kesediaan bekerja dari para aparat desa guna mencapai sasaran-sasaran organisasi maupun untuk memenuhi tujuan-tujuan pribadi.

Ketiga, kepala desa sebagai Liaison harus membangun dan menjaga komunikasi dengan kontak Internal desa maupun kontak eksternal. Adapun pendapat informan tentang hal tersebut, informan memberikan keterangan bahwa:

"Kepala desa selalu memberikan waktu luang untuk berinteraksi dengan teman sejawat, staf dan masyarakat tentunya untuk mendapatkan informasi”. (Bpk. Mugino selaku bendahara desa mamampang)

Terkait peran kepala desa sebagai Liaison untuk mendapatkan informasi, hal ini di sebut hubungan pertukaran (exchange realitionship) yakni pimpinan memberikan sesuatu agar mendapatkan sesuatu. Sementara mengenai komunikasi kontak internal informan lain mengatakan bahwa: 
"kami mengutamakan komunikasi yang baik, misalnya jika ada kegiatan desa atau ketika desa dalam kondisi tidak baik-baik saja, kami bekerja sama sampai desa menjadi baik, hal ini menurut kami sebagai jembatan terwujudnya pemerintahan desa yang baik. (Bpk. Anwar selaku kepala desa tonasa)

Berdasarkan wawancara tersebut, hasil penelitian menunjukkan bahwa kepala desa Tonasa Dan Desa Mamampang dalam menjalankan peran pemimpin bersifat interpersonal yang diukur berdasarkan penghubung atau liaison sudah cukup baik. Terbukti kepala desa Tonasa dan Desa Mamampang dapat menjalankan perannya sebagai liasion dalam memimpin sebuah pemerintahan desa yang dimana peran ini membangun dan memelihara kontak dalam dan di luar organisasi untuk memberikan informasi kepada pegawaipegawainya sehingga informasi yang didapatkan bisa menjadi dukungan menjalankan tupoksi sebagai pegawai sehingga meningkatkan kinerjanya. Berdasarkan hasil penelitian dapat dikatakan bahwa Peran pemimpin bersifat interperson yang diukur berdasarkan peran pemimpin sebagai penghubung sudah cukup baik dilaksanakan oleh kepala Desa Tonasa dan Desa Mamampang dibuktikan dengan terjalinnya kerjasama yang baik sesama pegawai.

2. Peran kepala Desa dalam Decision making (peranan pembuat keputusan)

Peran kepala desa dalam Decision making dapat dilihat dari perannya sebagai Entrepreneur, Distrubance handler, Resource allocation, dan Negotiator. Pertama, kepala desa sebagai Entrepreneur yaitu merupakan pemrakarsa dan perancang yang mulai dari aktivitas malihat dan memahami secara realiti persoalan-persoalan organisasi. Dalam peran ini kepala desa diharapkan menjalankan perannya seperti mengidentifikasi ide-ide pembaruan yang berfungsi untuk organisasi dan menerapkannya sehingga muncul inovasiinovasi dalam peningkatan sumber daya manusia di desa Tonasa dan Desa Mamampang. Adapun pendapat informan mengenai kepala desa sebagai Entrepreneur, informan memberikan keterangan bahwa:

"peran kepala desa sebagai perancang dari persoalan-persoalan desa, yaitu membuat pelatihan, memberikan fasilitas pendukung, dan memberikan pengembangan skill dan sofskill bagi setiap anggota-anggotanya”. (Bpk. Ikhsan selaku staf desa mamampang)

Sementara informan lain mengatakan:

"Saya selaku bagian dari staf desa, dengan sikapnya pak desa yang suka memberi ide-ide tentang bagaimana desa kedepannya, secara otomatis kualitas staf-staf desa akan meningkat karena adanya inovasi-inovasi dalam bekerja bisa tercipta lingkungan kerja yang nyaman bagi aparatur desa pada khususnya". (Bpk. Najamuddin selaku kepala dusun desa tonasa)

Dari kutipan wawancara tersebut membuktikan bahwa peran entrepreneur dijalankan dengan baik oleh kepala desa karena peran ini sangat berpengaruh pada kualitas pegawai. Dengan menjalankan peran ini, pegawai bisa meningkatkan kinerjanya karena perlunya membuat inovasi-inovasi dalam bekerja sehingga tercipta lingkungan kerja yang nyaman bagi pegawai.

Kedua, peran kepala desa sebagai Distrubance handler yaitu bertanggung jawab atas tindakan korektif bila organisasi menghadapi gangguan mendadak dan penting. Dalam 
peran ini, kepala desa Tonasa dan Desa Mamampang menjalankan perannya sebagai distrubance hendler yang dimana kepala desa langsung turun tangan bila ada gangguangangguan yang muncul yang bisa berakibat langsung pada pemerintahan desa. Adapun pendapat informan mengenai peran kepala desa sebagai Distrubance handler, informan memberikan keterangan bahwa:

"Peran yang diambil dalam setiap konflik yang terjadi antar staf dan aparat desa sangat signifikan memberikan semangat kerjasama serta saling bahu membahu dalam penyelesaian pekerjaan”. (Bpk. Ikhsan selaku staf desa mamampang)

Sementara informan lain mengatakan bahwa:

"Menurut saya, kami staf desa ini, butuh peran pemimpin yang bisa mengamankan jalannya kegiatan desa dan menjaga kekondusifan desa, khususnya bisa mengamalkan hablumminannas”. (Bpk. Darmawangsyah selaku kepala dusun desa mamampang)

Dari kutipan wawancara tersebut memaparkan bahwa peran kepala desa sebagai distrubance hendler dilakukan dengan sangat baik dimana untuk meningkatkan kualitas pegawainya butuh peran pemimpin yang bisa bertugas untuk mengamankan jalannya kegiatan desa dan menjaga kekondusifan dalam suatu desa. Dengan demikian, jika di lihat dari teori kepemimpinan yaitu teori sosiologis, kepala Desa Tonasa dan Mamampang termasuk di dalam teori tersebut.

Ketiga, peran kepala desa sebagai Resource allocation yaitu peran yang bertujuan mengambil atau menyetujui keputusan organisasi yang penting. Dalam peran ini kepala desa Tonasa dan Desa Mamampang mengambil suatu tindakan yang penting untuk organisasi dan memiliki kewenangan dalam mengendalikan penggunaan sumber daya organisasi. Adapun pendapat informan mengenai peran kepala desa sebagai Resource allocation, informan memberikan keterangan bahwa:

"Beliau selalu mementingkan musyawarah mufakat disetiap pengambilan keputusannya". (Bpk Darmawangsyah selaku kepala dusun desa mamampang)

Dari kutipan wawancara tersebut membuktikan bahwa kepala Desa Tonasa dan Desa Mamampang menjalankan peran resource allocation yang dimana peran ini peran yang tidak boleh tidak harus dijalankan karena peran ini berkaitan langsung dengan proses pembuatan keputusan yang berhubungan langsung dengan kinerja pegawai. Berdasarkan teori kepemimpinan yakni teori otokratis, kepala desa Tonasa dan Mamampang tidak termasuk dari pemimpin yang otokratis, dimana pemimpin yang selalu ingin merajai situasi. Kepala desa Tonasa dan Desa Mamampang mengutamakan musyawarah mufakat.

Keempat, peran kepala desa sebagai Negotiator yaitu peran yang bertanggung jawab mewakili organisasi pada perundingan utama . Dalam peran ini Kepala desa Tonasa dan Desa Mamampang diharapkan bisa menjadi peran yang menghubungkan suatu organisasi dengan organisasi lainnya apabila organisasi ini membutuhkan informasi dari organisasiorganisasi yang lain. Dalam wawancara terkait peran kepala desa sebagai Negotiator, informan mengatakan bahwa:

"kepala desa selalu menghadiri undangan-undangan musyawarah baik dari organisasi di desa maupun dari organisasi desa tetangga”. (Ibu Fitrah selaku staf desa tonasa) 
Dari kutipan wawancara tersebut bisa diketahui bahwa Kepala Desa Tonasa dan Desa Mamampang menjalankan peran negotiator yang dimana kepala desa berpartisipasi langsung dalam kegiatan negoisasi dengan organisasi lain dan individu.

3. Peran kepala desa dalam Informational role (peranan sumber informasi)

Peran pemimpin dalam informational role dapat dilihat dari peran kepala desa ditinjau dari Monitor and dessiminator dan Spoke person. Pertama, peran kepala desa sebagai Monitor and dessiminator yaitu peran yang menerima informasi sangat beraneka, berfungsi sebagai pusat saraf informasi luar dalam organisasi dan meneruskan informasi yang diterima dari luar atau dari bawahan lain kepada anggota organisasi. Adapun pendapat informan mengenai peran kepala desa sebagai Monitor and dessiminator, informan memberikan keterangan bahwa:

"Kepala desa menjalankan perannya dengan memantau setiap kegiatan yang ada di desa, maupun setiap pembangunan-pembangunan desa tidak pernah lepas dari pantauan kepala desa”. (Ibu Fitrah selaku staf desa tonasa)

Dari kutipan wawancara tersebut bisa diketahui bahwa dengan menjalankan peran monitor and dessiminator kepala desa Tonasa dan Desa mamampang dapat mengetahui keadaan organisasi dengan baik dan bisa mengatahui langsung masalah-masalah internal dalam pegawai sehingga bermanfaat bagi kinerja pegawainya. Hasil penelitian menunjukkan bahwa peran pemimpin bersifat informasial yang diukur berdasarkan peran pemimpin sebagai pemantau sudah cukup baik. Terbukti kepala desa mampu menjalankan peran sebagai pemantau pada setiap aktifitas. Dan dari peran pemimpin bersifat informasial yang diukur berdasarkan peran pemimpin sebagai pemberi informasi sudah cukup baik. Hal ini terlihat dalam melakukan penyampaian informasi dari luar ke dalam organisasinya, dan informasi yang berasal dari bawahan atau stafnya ke bawahan atau staf lainnya.

Kedua, peran kepala desa sebagai Spoke person yaitu peran yang meneruskan informasi kepada luar mengenai rencana, kebijakan, tindakan, dan hasil organisasi, berfungsi sebagai pakar mengenai kinerja organisasi. Dalam peran spoke person pemimpin diharapkan bisa menyampaikan informasi organisasinya kepada organisasi diluar. Adapun pendapat informan mengenai kepala desa sebagai Spoke person, informan memberikan keterangan bahwa:

"Bentuk transparansi desa menjadi bukti dari setiap perencanaan hingga hasil dari perencanaan itu sebagai informasi yang bisa di lihat oleh organisasi lain”. (Ibu Fitrah selaku staf desa tonasa)

Dari kutipan wawancara tersebut bisa dipastikan bahwa kepala desa Tonasa dan desa Mamampang menjalankan peran spoke person dalam peran ini juga pegawai bisa mengetahui sebagaimana kinerja pegawai dalam lembaga sehingga pegawai tersebut bisa meningkatkan kinerjanya.

Dengan adanya peran kepemimpinan yang di terapkan dalam pemerintahan desa, indikator kualitas sumber daya manusia berikut bisa di jadikan sebagai penilaian peran kepemimpinan dalam meningkatkan kualitas sumber daya manusia yang ada di pemerintah Desa Tonasa dan pemerintah Desa Mamampang. Sebagaimana Kualitas 
sumber daya manusia menurut Rucky (2003:57) menyatakan bahwa kualitas sumber daya manusia dapat di ukur dari tingkat pengetahuan, tingkat kemampuan, dan tingkat kemauan yang dapat ditunjukkan oleh sumber daya manusia. Dalam wawancara terkait kualitas sumber daya manusia, informan memberikan keterangan bahwa:

"Kualitas Sumber Daya Manusia adalah kemampuan sigap dan tanggap setiap anggota masyarakat dalam menghadapi segala sesuatu kemungkinan yang akan terjadi, baik dari segi sosial, ekonomi dan politik”. (Bpk. Anwar selaku kepala desa tonasa)

Terkait dengan hal tersebut kualitas sumber daya manusia, dimana Manusia merupakan salah satu unsur terpenting yang menentka berhasil atau idaknya suatu organisasi mencapai tujuan dan mengembangkan misinya. Menurut Sumardjan dalam Sedarmayani (2000) bahwa manusia seutuhnya yang berkualitas adalah manusia-manusia pembangunan yang memiliki ciri:

a) Mempunyai kepercayaan atas dirinya sendiri, tidak boleh rendah diri yang menimbulkan sikap pasrah atau menyerah pada nasib, sehingga ia menjadi pasif atau apatis terhadap kemungkinan untuk memperbaiki nasibnya. Terkait ciri tersebut, informan memberikan keterangan bahwa:

"Saya rasa sikap rendah diri itu termasuk akhlak mazmumah atau buruk, jadi kami yang tentu memegang jabatan tidak lepas dari pujian dan juga celaan dari siapaun tetapi dengan begitu kami belajar bagiamana mengedepankan sikap rendah hati agar bisa menerima celaan orang lain dan juga mensyukuri pujian orang”. (Bpk. Darmawangsyah selaku kepala dusun desa mamampang)

b) Mempunyai keinginan yang kuat untuk memperbaiki nasibnya. Hal ini sejalan dengan keterangan informan bahwa:

"Saya termotivasi dari perjalanan hidup pak desa, dari batu krikil sampai batu gunung yang menjadi rintangannya bisa beliau lalui, saya hanya percaya bahwa yang ada tidak sealamaya ada, begitupun sebaliknya". (Bpk. Najamuddin selaku kepala dusun desa tonasa)

c) Mempunyai watak yang dinamis antara lain Memanfaakan setiap kesempatan yang menguntungkan, mampu memecahkan persoalan hidup yang dihadapi, Selalu siap menghadapi perubahan social budaya yang terjadi dalam masyarakat, bersedia dan mampu bekerja sama dengan pihak lain atas dasar pengertian dan penghormatan hak sera kewajiban masing-masing pihak. Terkait ciri-ciri tersebut, informan memberikan keterangan bahwa:

"Kami di desa, jika ada masalah-masalah pribadi ataupun persoalan-persoalan di desa yang mungkin tidak bisa di selesaikan sendiri, terkadang kami kumpul bersama kemudian saling berbagi solusi”. (Bpk. Darmawangsyah selaku kepala dusun desa mamampang)

Informan lain mengatakan bahwa: 
"Kami kalau lagi kurang semangat dalam bekerja, mungkin karena bagian dari kepekaan sosialnya pak desa, beliau membuka wadah perkumpulan agar kami bisa menjelaskan mengapa kami terlihat kurang semangat, kemudian pak desa sering memberi kita motivasi untuk bangkit, terkadang setelah itu kami mulai semangat kembali”. (Bpk. Najamuddin selaku kepala dusun desa tonasa)

d) Mempunyai watak yang bermoral tinggi, antara lain: jujur, menepati janji, dan peka hak dan kepentingan pihak lain. Terkait ciri ini, informan memberikan keterangan bahwa:

"Jika melihat dari kejujuran staf-staf desa di sini, saya rasa mereka memegang teguh sifat amanah mereka, saya sering mengingatkan kepada mereka sebuah motivasi dari perjalanan seorang prajurit, bahwa prajurit tidak akan menangis hanya karena kematian tetapi akan menangis karena penghianatan. Dari sini, tentu mereka bisa sadar bahwa kita hidup hanya sekali, mati sekali, dan kepercayaan juga hanya sekali”.

\section{(Bpk. Anwar selaku kepala desa tonasa)}

Berdasarkan beberapa kutipan dari ciri-ciri dari sumber daya manusia yang berkualitas tersebut, menjadi postulat bahwa kualitas sumber daya manusia atau kualitas aparatur desa di desa Tonasa dan Mamampang terbilang berkualitas yang pastinya tidak lepas dari peran kepala desa sebagai pemimpin yang berjiwa besar.

Konteks kualitas sumber daya aparatur di era modern ini adalah kemampuan professional dan keterampilan teknis para pegawai, termasuk kepada unsur staf dan pelaksana di lingkungan Pemerintah desa. Dalam wawancara terkait kualitas sumber daya manusia, informan menyatakan bahwa:

"Kualitas SDM yang mumpuni mampu mendobrak inovasi dan kreatifitas suatu desa dalam menghadapi persaingan global yang semakin pesat di era 4.0 ini”. (Bpk. Anwar selaku kepala desa tonasa)

Hal ini sangat diperlukan agar manajemen pemerintahan desa dapat berlangsung secara efektif dan efisien.Yang diperlukan tidak hanya jumlahnya yang cukup, tetapi juga kualitas para pegawai yang harus diukur dengan melihat latar belakang pendidikan, keterampilan, pengalaman kerja, jenjang kepangkatan dan status kepegawaian. Bertolak dari beberapa pendapat diatas, maka yang dimaksud dengan kualitas sumber daya aparatur adalah tingkat pendidikan dan pelatihan, pengalaman, kinerja yang dmiliki oleh aparatur dalam melaksanakan aktivitas-aktivitas yang menjadi tanggung jawab anggotanya untuk mencapai tujuan organisasi melalui:

a) Pendidikan dan Pelatihan (Diklat)

Menurut Siagian (1998) bahwa "Pendidikan adalah keseluruhan proses, teknik dan metode belajar mengajar dalam rangka mengalihkan sesuatu pengetahuan dari seseorang kepada orang lain sesuai dengan standar yang telah ditetapkan sebelumnya". Nawawi (2000) mengatakan bahwa "Pelatihan merupakan peningkatan keterampilan kerja yag dibutuhkan untuk melaksanakan pekerjaan seseorang dan dapat digunakan untuk pengembangan pegawai dalam menghadapi peningkatan tanggungjawabnya di masa mendatang bersamaan dengan peningkatan kepangkatannya serta dilakukan untuk pegawai lama dan baru." 
Dalam wawancara terkait pentingnya pendidikan dan pelatihan sebagai alat ukur dari kualitas sumber daya manusia di lingkup desa, informan memberikan keterangan bahwa:

"Pernah ada pelatihan terkait penerapan aplikasi pengelolaan keuangan desa, saya terjunkan bendahara desa, sekertaris desa dan beberapa staf lain untuk mengikuti pelatihan tersebut, karena menurut saya itu termasuk dari tanggungjawab besar kepala desa untuk membidik prinsip transparansi terhadap publik pada umumnya, dan penduduk desa pada khususnya”. (Bpk. Anwar selaku kepala desa tonasa)

Berdasarkan UU Nomor 20 Tahun 2003 bahwa, "Pendidikan adalah usaha sadar dan terencana unuk mewujudkan suasana belajar dan proses pembelajaran agar peserta didik secara aktif mengembangkan potensi dirinya untuk memiliki kekuatan spiritual keagamaan, pengendalian diri, kepribadian, kecerdasan, akhlak mulia serta keterampilan yang diperlukan dirinya, masyarakat, bangsa dan Negara." Bertolak dari beberapa pendapat di atas, maka yang di maksud dengan pendidikan dan pelatihan adalah keseluruhan proses, teknik dan metode untuk menambah pengetahuan dan keterampilan bekerja sesuai dengan standar yang telah di tetapkan sebelumnya, sehingga dengan demikian dapat meningkatkan produktifitas kerja.

b) Pengalaman

Pengalaman menurut kata pribahasa adalah" guru yang terbaik". Saydam (1996) mengemukakan bahwa pengalaman yang dimiliki pegawai lebih banyak membuat dalam mengerjakan sesuatu di bandingkan dengan pendidikan yang diikutinya. Karena pengalaman akan memberikan kemahiran dan keterampilan bagi pegawai untuk berbuat sesuatu. Seperti keterangan yang diberikan oleh informan, mengatakan bahwa:

"Semakin sering kami kirimkan aparatur desa untuk mengikuti pelatihan, maka bisa menciptakan banyak pengalaman, kami di desa mungkin saja masih ada beberapa yang terlihat kaku, tetapi walaupun begitu mereka hnaya perlu proses untuk berubah, jalannya yah mereka perlu banyak pengalaman”. (Bpk. Mugino selaku bendahara desa mamampang)

Informan lain mengatakan bahwa:

"Saya semangat ikut pelatihan apabila di amanahkan oleh kepala desa, karena bagi saya guru paling besar itulah pengalaman”. (Bpk. Darmawangsyah selaku kepala dusun desa mamampang)

Berdasarkan kutipan tersebut, kualitas sumber daya manusia di lihat dari pengalaman pegawai di desa Tonasa dan Mamampang sudah berkualitas karena adanya peran kepala desa sebagai tangan yang membimbing para pegawainya untuk menjadi pegawai yang berkualitas.

c) Kinerja

kinerja menurut Lembaga Administasi Negara (LAN) dalam Supriyatna (2000) adalah "Prestasi kerja, pelaksanaan kerja, mencapai kerja atau hasil kerja atau 
penampilan kerja yang diterjamahkan dari "performence". Sedangkan Fieldman dalam Supriyatna (2000) mengemukakan bahwa "Prinsip dasar manajemen adalah kinerja yang merupakan perpaduan antara motivasi yang ada pada diri seseorang dan kemampuannya dalam melaksanakan suatu pekerjaan". Dalam wawancara terkait kinerja, informan memberikan keterangan bahwa:

" Meningkatnya kinerja pegawai itu karena adanya pemimpin yang bisa selalu memberi ruang kebersamaan tanpa penekanan, tetapi dengan penegasan. Contohnya seperti, masalah disiplin waktu, jam datang jam istrahat jam pulang, mereka di beri penegasan, cuman kadang kala dari pegawainya juga yang mungkin karena ada halangan atau alasan apa sehingga bisa terlambat dan tidak sesuai dengan aturan". (Bpk. Mugino selaku bendahara desa mamampang)

Informan lain mengtaakan bahwa:

"Kami selalu berusaha untuk hadir tepat waktu, dan kalaupun akan terlambat kami biasanya menitip kabar bahwa kami akan terlambat”. (Bpk. Najamuddin selaku kepala dusun desa tonasa)

Berdasarkan wawancara tersebut, peran pemimpin dalam kualitas sumber daya manusia dilihat dari kinerja, sudah mumpuni, karena jika di lihat dari masalah kedisiplinan waktu di setiap organisasi yang ada di Indonesia secara umum, masih jauh dari kata disiplin. Teori kepemimpinan yaitu teori suportif, peran kepala desa di desa Tonasa dan desa Mamampang dalam meningkatkan kualitas sumber daya manusianya sudah merupakan bagian dari pemimpin yang suportif.

\section{Kesimpulan}

Peran kepemimpinan dalam meningkatkan kualitas sumber daya manusia di desa tonasa dan desa mamampang dapat di lihat berdasarkan peran kepala desa sebagai Interpersonal role (Peranan pribadi), Decision making (peranan pembuat keputusan), dan Informational role (peranan sumber informasi). Dari hasil penelitian, kami menyimpulkan bahwa dari ketiga peran pemimpin tersebut sudah di jalankan oleh kepala desa di desa tonasa dan desa mamampang dimana dalam interpersonal role kepala desa menempatkan dirinya sebagai Figurehead, Leader dan Liaison. Sebagai Figurehead, misalnya menjadi sumber inspirasi bagi pegawainya. Sebagai Leader, misalnya menjadi sang motivator untuk mencapai sasaran pemerintahan yang baik. Dan sebagai Liaison, misalnya kepala desa mengutamakan komunikasi yang lancar demi terjalinnya kerjasama yang baik sesama pegawai. Selanjutnya dalam Decision making, kepala desa menempatkan dirinya sebagai Entrepreneur, Distrubance handler, Resource allocation, dan Negotiator. Dan dalam Informational role kepala desa menempatkan dirinya sebagai Monitor and dessiminator dan Spoke person. Yang dengan adanya ketiga peran pemimpin tersebut menciptakan sumber daya manusia yang berkualitas, dimana kepala desa berpedoman bahwa kualitas Sumber Daya Manusia adalah kemampuan sigap dan tanggap setiap anggota masyarakat dalam menghadapi segala sesuatu kemungkinan yang akan terjadi, baik dari segi sosial, ekonomi dan politik. 


\section{Daftar Pustaka}

Afandi, P. (2018) "Manajemen Sumber Daya Manusia (Teori, Konsep dan Indikator)". Riau: Zanafa Publishing.

Ali, Akbar. (2009) "The Role of Leadership in Human Resource Management a Comparative Study of Specific Public and Private Sectors in Pakistan”. Jurnal of Management and Sosial Sciences.

Amin T. Yuliana Fadillah dan R.M. (2013) "Efektivitas Penyelenggaraan Pemerintah Desa". Volume 11, Nomor 2, http://jurnalpemerintahandesa.net.

Azwar, Azrul, (1996) "Menjaga Mutu Peayanan Kesehatan”. Pustaka Sinar Harapan, Jakarta.

Badeni. (2014). "Kepemimpinan Dan Perilaku Organisasi”. Bandung: Alfabet.

Bali, Dominggus, Adhitama, Muhammad Okto. (2019) "Peran Kepemimpinan Kepala Desa Dalam Pembangunan Sumber Daya Manusia". Jurnal Ilmu Sosial Dan Ilmupolitik Issn. 2442-6962 Vol. 8 No. 42019.

Bunga, Susanti. (2015) "Kepemimpinan Camat Dalam Meningkatkan Kinerja Pegawai Pada Kantor Camat Tobelo Selatan”. Universitas Sam Ratulangi.

Dacholfany. M.I, Eko Susanto dan Andi Noviandi. (2018) "Leadership and Management of Education Institutions in Improving Human Resources in Indonesia”. Journal of Economic and Business Management in American.

Hardiansyah Muhammad, Muhammad Arif Nasution, Dan Armansyah Matondang, (2019) "Efektivitas Pelayanan Perangkat Desa Oleh Kepemimpinan Kepala Desa (Datuk Penghulu)".

Hersona., Sonny., \& Sidharta, I. (2017) "Influence of Leadership Function, Motivation And Work Discipline On Employees' Performance". Journal of Applied Management (JAM) Volume 15 Number 3, September 2017: 528-537.

Hijriah. (2019) "Pengaruh Kepemimpinan Terhadap Pengembangan Sumber Daya Manusia Dilingkup Sekretariat Dewan Perwakilan Rakyat Daerah Kabupaten Mamuju Utara”.

Jaishartine, Charolena. (2016). "Peran Kepala Inspektorat Dalam Meningkatkan Kinerja Pegawai Pada Kantor Inspektorat Kabupateb Malinau”. Universitas Mulawarman.

Juliani, Retno Djohar. (2016) "Peran Pemimpin Dalam Meningkatkan Kinerja Karyawan Melalui Kemampuan Motivasi, Membangun Hubungan Yang Efektif, Merencanakan Dan Menerapkan Perubahan Dalam Organisasi". Majalah Ilmiah Inspiratif.

Kumalasari Intan. (2016) "Kepemimpinan Kepala Desa Ciamis Dalam Pembangunan Desa (Studi Pada Gaya Kepemimpinan Situasional Kepala Desa Ciamis Kecamatan Sungkai Utara Kabupaten Lampung Utara)".

Kushandajani dan Indah A.P. (2020) "Inovasi Pemberdayaan Masyarakat Desa: Peran Kepemimpinan Lokal dalam Peelrspektif Relasi Antar Aktor". Jurnal Ilmiah Ilmu Pemerintahan.

Kusuma,Lucky. P. B. dan Hade Afriansyah. (2019) "Peningkatan Manajemen Mutu Pendidikan Melalui Sumber Daya Manusia". Jurnal Administrasi Pendidikan.

Lahada, Galip. (2018) "Kepemimpinan Kepala Desa Dalam Pelaksanaan Pembangunan Dan Kemasyarakatan Di Desa Malei Lage Kecamatan Lage Kabupaten Poso”. Jurnal Ilmiah Administratie Volume : 11 Nomor : 1 Edisi : September 2018

Liyas, N.J. (2017) "Pengaruh Kepemimpinan Terhadap Disiplin Kerja Karyawan pada PT. Bank Syariah Mandiri”. JEBI (Jurnal Ekonomi dan Bisnis Islam)-Volume 2, Nomor 2, Juli-Desember 2017: 121-129.

Mardiasmo (2020) “Akuntansi Sektor Publik”. Yogyakarta: Andi. 
Mishra., Adya., \& Mahapatra, M. 2018. Servant Leadership A Necessity For Competitive Advantage. Journal of Business Management \& Social Sciences Research (JBM\&SSR) Volume 7, No.2, February 2018: 40-44.

Mokodompis, Hendra. (2011) "Pengaruh Kualitas Sumber Daya Manusia Aparatur Terhadap Peningkatan Kinerja Di Badan Kepegawaian Daerah Kabupatenbolaang Mongondow Utara".

Purba, Kristiana, dkk. (2010) "Peranan Kepala Desa Dalam Meningkatkan Efektivitas Pelayanan Publik (suatu Studi di Desa Pinabetengan Selatan Kecamatan Tompaso Barat Kabupaten Minahasa)".

Rahmi, Sri. (2014) “Kepemimpinan Transformasional Dan Budaya Organisasi”. Jakarta: Mitra Wacana Media.

Rucky, Ahmad S. (2003) "Sumber Daya Manusia Berkualitas (Mengubah Visi Menjadi Realitas)". Penerbit PT. Gramedia Pustaka Umum, Jakarta.

Sineke, Afdullah, Dkk. (2017) "Kepemimpinan Kepala Desa Dalam Meningkatkan Pelayanan Publik Di Desa Atoga Timur Kecamatan Motongkad".

Srouji, M.F, Muhammad Ahmar bin Ali, Madher, E.H. (2015) "Leadership Management and Human Resource Perpectives". International Journal of Economics, Commerce and Management.

Suardi Reza Hafikar. (2017) "Peran Pemimpin Dalam Meningkatkan Kinerja Pegawai (Studi Kasus : Pkp2a Ii Lembaga Administrasi Negara (Lan) Kota Makassar)".

Sugiono (2009) "Penelitian Kualitatif".

Sulfiandy, Munif Arfan, Hilmy W, and Nur Awaliah.R. (2019) "Peran Kepemimpinan Dalam Meningkatkan Kinerja Pegawai”. Jurnal ResearchGate.

Syafitri Indriani dan Lilis Suriani. (2019) "Peran Kepemimpinan Kepala Desa Dalam Pelaksanaan Pembangunan Di Desa Sejati Kecamatan Rambah Hilir Kabupaten Hulu".

Undang-Undang Nomor 25 Tahun 2009 Tentang Pelayanan Publik

Undang-Undang Nomor 32 Tahun 2004 Tentang Pemerintahan Desa

Wiandari Ida Ayu Andini dan Gede Sri Darma. (2017) "Kepemimpinan, Total Quality Management, Perilaku Produktif Karyawan, Kinerja Karyawan dan Kinerja Perusahaan".

Yahdiani, Nurilatul Rahmah. A.R. Muna. Septi Nurjanah dan Sri Wahyuni. (2020) "Peran Kepemimpinan Kepala Sekolah dalam Meningkatkan Kualitas Peserta Didik di SDN Martapuro 2 Kabupaten Pasuruan”. EduPsyCouns Journal.

Yusuf (2016) "Peranan Kepemimpinan Terhadap Disiplin Kerja Pegawai Pada Kantor Bagian Hukum Sekretariat Daerah Kabupaten Kutai Barat”. eJournal Psikologi. 5 (3). 